\title{
An Infrastructure Financing Scheme for Industrial Development
}

\author{
Mohammed Ali Berawi ${ }^{1,2^{*}}$, Cantika Rahmalia Putri², Mustika Sari², Agatha Vania Salim², \\ Gunawan Saroji², Perdana Miraj2,3 \\ ${ }^{1}$ Department of Civil and Environmental Engineering, Faculty of Engineering, Universitas Indonesia, \\ Kampus UI Depok, Depok 16424, Indonesia \\ ${ }^{2}$ Center for Sustainable Infrastructure Development, Faculty of Engineering, Universitas Indonesia, Kampus \\ UI Depok, Depok 16424, Indonesia \\ ${ }^{3}$ Management of Built Environment, Delft University of Technology, Delft 2628, Netherlands
}

\begin{abstract}
To achieve its vision of becoming a developed and prosperous economy in 2045, Indonesia focuses on expanding its regional development by developing its six economic corridors based on each corridor's potential industries. Therefore, adequate infrastructure that improves regional connectivity and drives economic activities should be developed to help accelerate the industrial development in each economic corridor. This paper examines the financial feasibility of investing in industrial supporting infrastructure projects and develops financing and institutional schemes for the implementation of public-private partnerships to enhance the attractiveness of the projects for the private sector. The results of life-cycle cost analysis and system dynamics simulation show that with a required initial cost of USD 254 million and operation and maintenance (OM) cost of USD 224.29 million, the development is deemed financially feasible, generating a revenue of USD 872.38 million for a 40 -year concession period. From the 45 cost-sharing scenarios investigated, the optimal internal rate of return (IRR) value of $15.62 \%$ was obtained, with the private sector covering $64.14 \%$ of the initial cost and $73.61 \%$ of the $\mathrm{OM}$ cost, as well as gaining $76.62 \%$ of the total revenue.
\end{abstract}

Keywords: Financing scheme; Industrial development; Infrastructure projects; Public-private partnership

\section{Introduction}

As stated by President Joko Widodo in the Vision of Indonesia 2045, an optimistic goal to become a developed country and the fifth-largest economy in the world has been set for Indonesia when it marks its 100th anniversary of independence in 2045 (Negara and Ramayandi, 2020). To realize this vision, the government has committed to reforming its resource-based economy into an economy based on manufacturing and modern services by investing in equitable infrastructure regional development that is adequate and wellintegrated (Tijaja and Faisal, 2014). The development is focused on increasing connectivity with economic growth centers and decreasing disparities among regions

The Master Plan for Acceleration and Expansion of Indonesia's Economic Development (MP3EI) was established by the government to achieve equitable regional development. In this master plan, Indonesia's regions are divided into six economic corridors, which include the Sumatera Corridor, Java Corridor, Kalimantan Corridor, Sulawesi Corridor, Bali-Nusa 
Tenggara Corridor, and Papua-Maluku Corridor, with the integration of three essential elements: the development of six economic corridors, improvement of integrated connectivity, and acceleration of the human resource capacity and development of science and technology to support each corridor's economic activities (Berawi et al., 2020).

Previous research has shown that economic growth is positively affected by the development of infrastructure assets (Komarova et al., 2014); a higher number of infrastructure assets as well as their higher quality can reduce income inequality (Calderón and Servén, 2004), which implies that infrastructure development has the potential to reduce poverty (López, 2003) effectively. These positive impacts can be attributed to the increased production capacity prompted by the provision of industrial infrastructure (e.g., factories and smelters) and the increased ease of mobility and transportation to distribute commodities and deliver services provided by transportation infrastructure, such as roads, ports, airports, and docks (Palei, 2015; Snieška and Bruneckiene, 2009).

Despite its positive impacts, infrastructure development requires a very high financial cost (Hansen et al., 2018). The Indonesian National Planning Agency/Bappenas (2020) estimated that the government could only cover $37 \%$ of the budget required to finance infrastructure development. Consequently, there is a financing gap that needs to be covered by other sources, for example, through partnership with the private sector, known as the public-private partnership (PPP) scheme.

Research on the industrial development conducted in these past few years shows that its acceleration could be achieved by considering the characteristics of competitiveness and the region's potential resources (Timmer et al., 2011). Several papers have also recommended investment in urban development and connectivity infrastructure to support industrial development, providing mobility and accessibility for humans and goods (Azolibe and Okonkwo, 2020; Zhang et al., 2021). However, these studies have not yet developed a project financing scheme.

In addition, studies on PPP implementation in Indonesia have also been conducted extensively in the past five years, focusing on financing roads and water supply infrastructure projects (Mandasari and Wahyuni, 2019). Although the financial feasibility of the PPP scheme for infrastructure and regional development has been widely investigated in various project developments, there is still minimal evidence regarding discussions on PPP financing and institutional schemes for industrial infrastructure development. Therefore, this study aims to develop an optimal PPP financing scheme that can increase the private sector's interest in participating in industrial infrastructure projects and formulate an institutional scheme to guarantee project sustainability. The findings of this study are expected to contribute to the body of knowledge on PPP financing schemes for infrastructure projects.

\section{Methods}

This study adopted both qualitative and quantitative approaches to obtain its two research objectives. The qualitative approach was used by conducting a series of literature studies, benchmarking, and in-depth interviews with experts. As for the quantitative approach, the life-cycle cost (LCC) analysis technique calculating the cost of project development considering all project stages, starting from the conceptualization, development, operation, and maintenance phases, was conducted to determine the financial feasibility of investment (Blank and Tarquin, 2013; Piroozfar et al., 2016).

An extensive literature study was conducted to gather data and insights on the industrial potencies of each economic corridor and the required supporting infrastructures. This was followed by benchmarking this study to a previous study by Berawi et al. (2018) 
to estimate the cost components in the LCC analysis, which were further adjusted by considering the difference in the research period and the construction cost index between the benchmark and this study to fit the time value for money.

A system dynamics (SD) modeling that is suitable to assess the dynamic nature of microeconomic occurrences was conducted to estimate the revenue stream for a project utilizing PowerSim software (Sterman, 2000; Yuliawati et al., 2015). Since the study was conducted in 2020, the inflation rate and interest rate were set in the LCC analysis based on the average rates published by Bank Indonesia (2021) for the years 2017-2019, at 3.15\% and $5.1 \%$, respectively. Along with the benchmarked cost components, the SD simulation results illustrated in the stock flow diagram (SFD) were then used to calculate the net present value (NPV) and the internal rate of return (IRR) of the project to determine its financial feasibility.

NPV is the difference between income and expenses discounted to a present value that calculates the costs and benefits suitable to estimate the investment cash flow for a project that was conducted for a long period, such as infrastructure with the PPP scheme (Kelly et al., 2003). The investment is considered feasible if NPV $>0$. The formula can be expressed as follows:

$$
N P V=\sum_{t=0}^{n} \frac{\left(R_{t}\right)}{(1+i)^{t}},
$$

where $R_{t}$ is the net cash flow during a time $t, i$ is the discount rate, and $t$ is the number of cash flow time.

IRR is a method for evaluating the profitability of a project investment depending on whether the value reaches the rate of return set (Strano et al., 2013). The formula for the IRR is as follows:

$$
I R R=i_{1}+\frac{N P V_{1}}{\left(N P V_{1}-N P V_{2}\right)}\left(i_{2}-i_{1}\right)
$$

where $i_{1}$ is the lower discount rate chosen $N P V_{1}=$ NPV at $i_{1}$, and $i_{2}$ is the higher discount rate chosen $N P V_{2}=\mathrm{NPV}$ at $i_{2}$.

The project is deemed feasible if the IRR exceeds the weighted average cost of capital (WACC) value, the weighted average of the overall capital structure, such as cost of equity and cost of debt (Mian and Vélez-Pareja, 2007). A WACC of 11.01\% was used for Indonesia's construction and materials sector in this study (WACC Expert, 2020).

Then, financial engineering simulating the cost and revenue sharing scenarios between the public and private sectors was performed to increase the project investment's attractiveness further. The IRR and NPV from each scenario were then estimated from the financial engineering simulations.

Furthermore, to develop a viable PPP scheme for project development, the first step taken was to conduct benchmarking studies from various PPP infrastructure projects worldwide in order to examine the governance cooperation between stakeholders in the joint investment and risk-sharing for the development of infrastructure projects in other countries. The results from the benchmarking study were then associated with the most optimal financing scheme to define the distribution of responsibilities between the government and the private sector in the PPP scheme. Subsequently, the determined division of responsibilities was used to formulate the institutional scheme. The results of this research were then validated by conducting in-depth interviews with experts from several institutions representing stakeholders in PPP infrastructure project development in Indonesia. The research framework can be seen in Figure 1 below. 


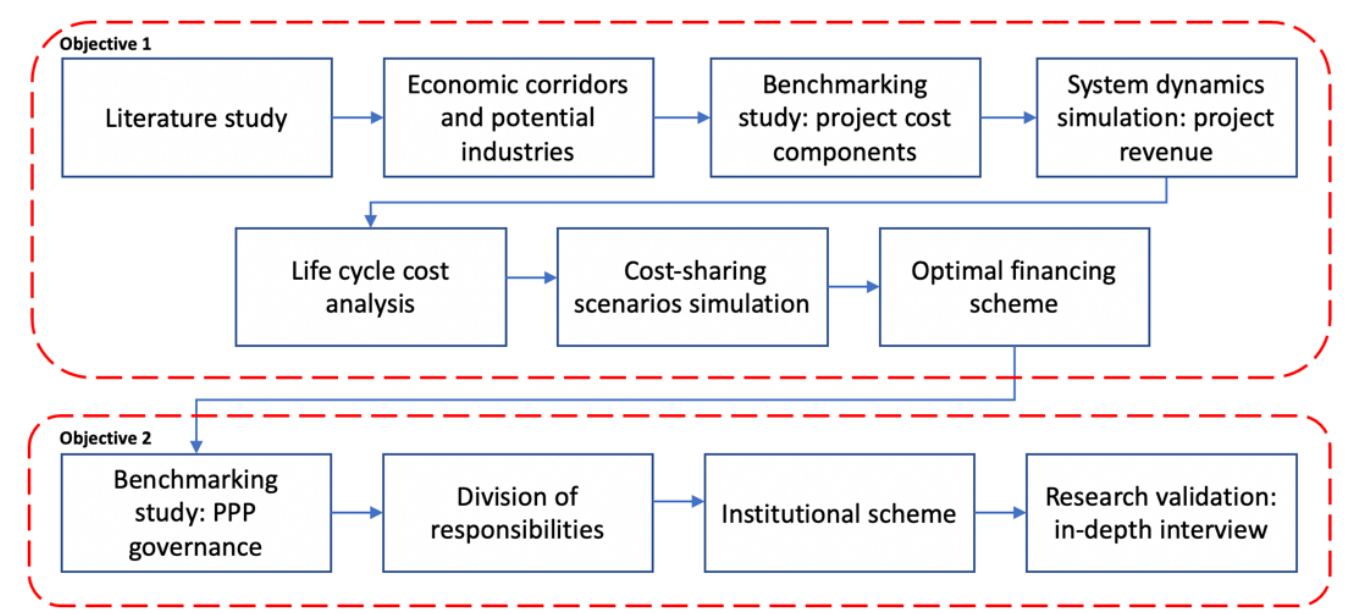

Figure 1 Research framework

\section{Results and Discussion}

\subsection{Potential Industries and Required Infrastructure for the Economic Corridors}

Previous studies have identified the main potential subsectors and the infrastructure development plan in each corridor (Berawi et al., 2020). The themes for each corridor, considering their potential for economic and industrial development, are shown in Figure 2 .

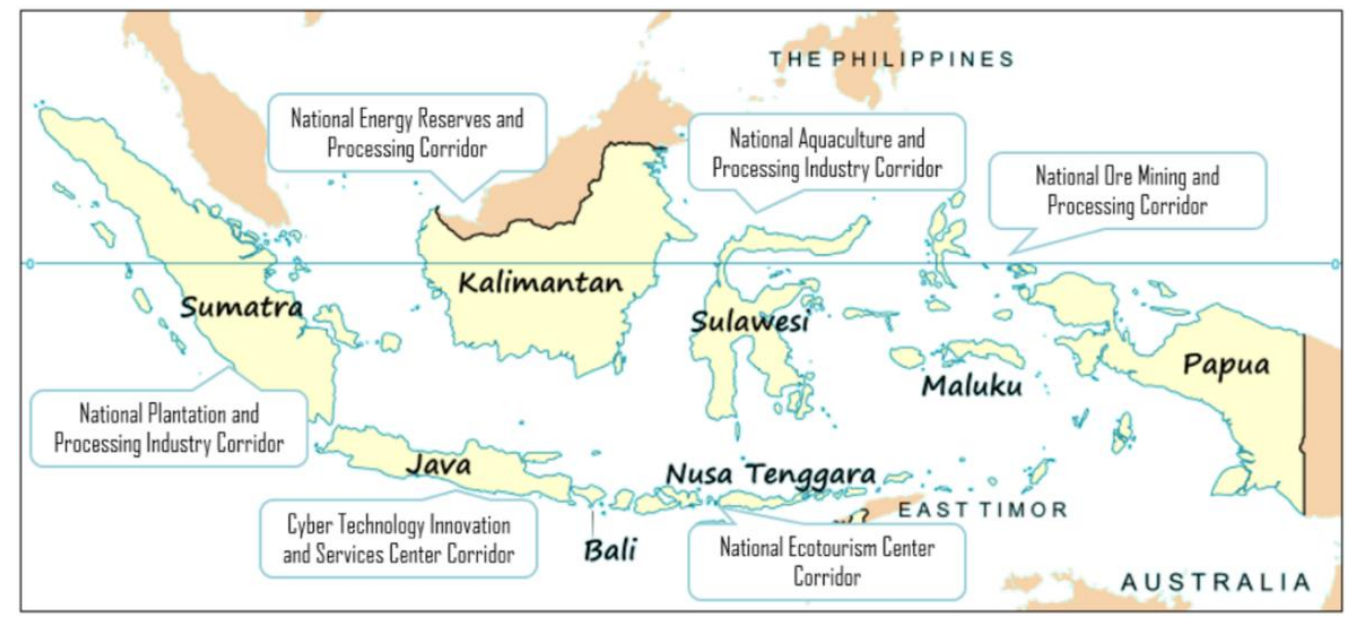

Figure 2 Indonesian economic corridors and potential industries (Berawi et al., 2017)

Plantation has the highest gross regional domestic product (GRDP) compared with the other subsectors in the Sumatera corridor, with coconut, palm oil, rubber, sugarcane, coffee, and pepper as the leading commodities. Therefore, it requires factories and research and development (R\&D) facilities, as well as other supporting infrastructures such as highways, railroads, ports, airports, and energy infrastructure. Conversely, the most potential industry in the Java corridor is the information and communication technology (ICT) sector; hence, the required industrial infrastructures consist of factories (e.g., semiconductor and gadget assembly) and techno-parks, as well as railroads, ports, airports, electricity, and ICT infrastructure.

Furthermore, the direction of industrial development in the Kalimantan corridor should be focused on the coal and lignite mining sectors, which require upgraded brown coal (UBC) factories, railways, ports, airports, electricity, toll roads, and ICT infrastructure. However, the primary potential industry in the Sulawesi corridor is the fisheries subsector, 
focusing on the sister fish, grouper, pompano, seaweed, shrimp, and milkfish from both marine and pond cultivations. Therefore, it requires industrial infrastructure such as smart floating farms (SFF), cold storages, snapper processing plants, grass agar factories, carrageenan factories, chitin and chitosan factories, milkfish processing factories, and other supporting infrastructures.

In the Bali-Nusa Tenggara corridor, tourism is a potential sector focusing on the accommodation and food and beverage subsectors. Therefore, it is crucial to improve connectivity by developing road infrastructure to support the industry. On the other hand, industrial development in the Papua-Maluku Islands corridor lies in the metal ore mining subsector producing mineral ores, particularly gold and copper commodities. Thus, nondiesel power plants and hydropower plants, port capacity and facilities, connectivity to the Jayapura Airport, and road access from the mineral ore industrial area to the port should be developed.

\subsection{Life-cycle Cost Analysis}

\subsubsection{Initial cost}

The initial cost components in this research were acquired through a case study and via benchmarking and iterations to previous studies that consider the time value of money. After conducting benchmarking to identify the value of each initial cost component in all corridors, the obtained total initial investment cost required to build industrial infrastructure was calculated to be USD 254 million. The details of the initial cost in each corridor are shown in Table 1.

Table 1 Total initial cost

\begin{tabular}{lrr}
\hline \multicolumn{1}{c}{ Corridor } & \multicolumn{2}{c}{ Initial Cost } \\
\hline Sumatera Corridor & USD & $71,087,372,012$ \\
Java Corridor & USD & $117,268,183,223$ \\
Kalimantan Corridor & USD & $17,696,650,475$ \\
Sulawesi Corridor & USD & $18,951,806,510$ \\
Bali-Nusa Tenggara Corridor & USD & $16,718,661,744$ \\
Papua-Maluku Corridor & USD & $12,841,921,344$ \\
\hline TOTAL & USD & $254,564,595,307$ \\
\hline
\end{tabular}

\subsubsection{Operation and maintenance cost}

The operation and maintenance $(\mathrm{OM})$ costs were estimated based on all the financial assumptions obtained from the benchmarking study. The calculation starts in 2025 until the infrastructure development has been completed. Table 2 shows the NPV of the estimated $\mathrm{OM}$ cost in each corridor.

Table 2 Total OM cost

\begin{tabular}{lrr}
\hline \multicolumn{1}{c}{ Corridor } & \multicolumn{1}{c}{ OM Cost } \\
\hline Sumatera Corridor & USD & $36,904,532,959$ \\
Java Corridor & USD & $101,695,544,009$ \\
Kalimantan Corridor & USD & $9,951,123,248$ \\
Sulawesi Corridor & USD & $30,259,275,716$ \\
Bali-Nusa Tenggara Corridor & USD & $6,467,891,314$ \\
Papua-Maluku Corridor & USD & $39,013,233,571$ \\
\hline TOTAL & USD & $224,291,600,816$ \\
\hline
\end{tabular}

\subsubsection{Revenue}

Revenue was calculated based on the projections of industrial capacity productions, selling prices, and sales success rate, where the input for the calculation was based on 
various components in the industrial development towards Indonesia's 2045 vision. Figure 3 shows the SD simulation, estimating a total revenue of USD 872.38 million (see Table 3 ).

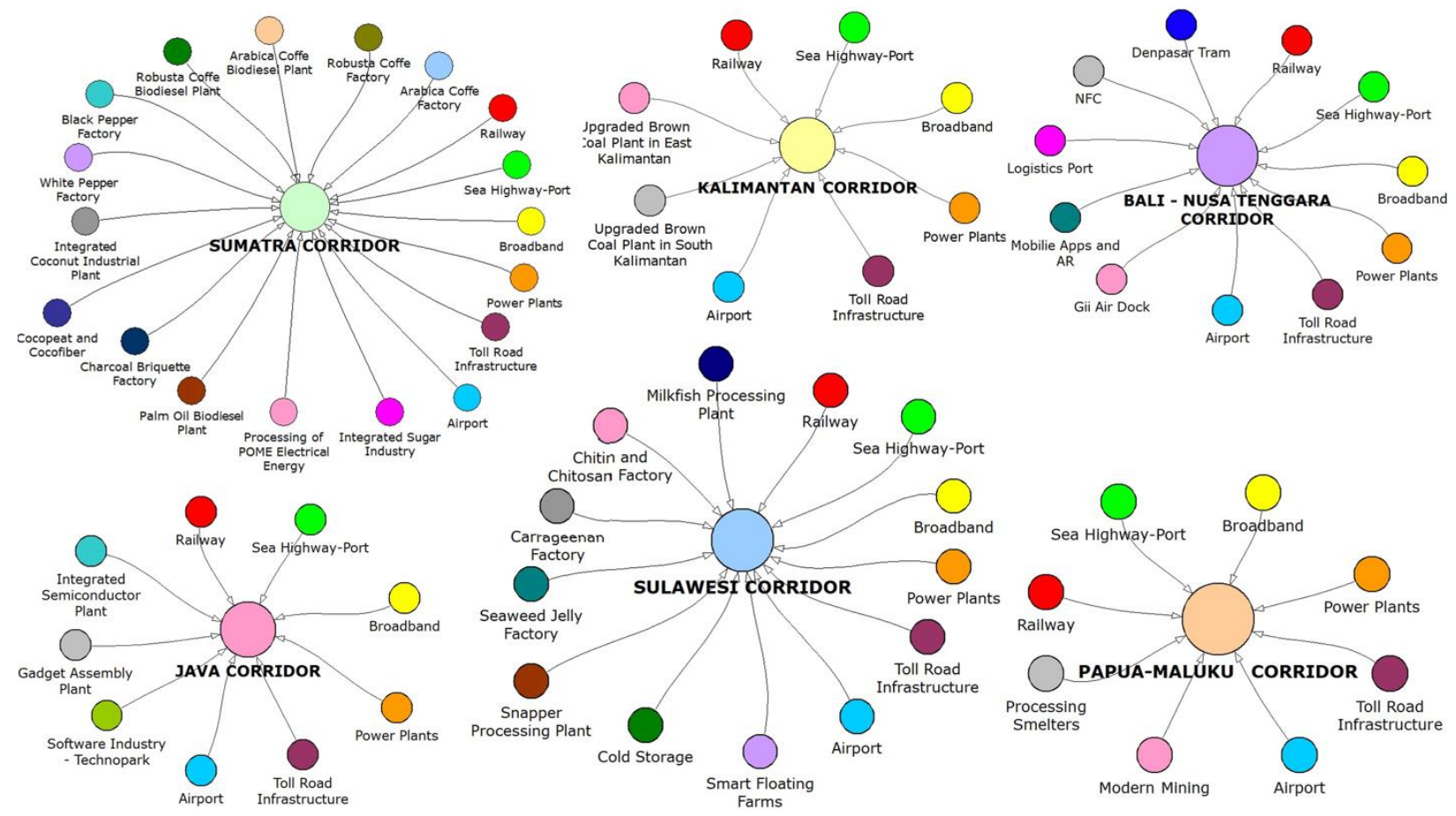

Figure 3 SFD of the infrastructure development in six economic corridors

Table 3 Total revenue

\begin{tabular}{lrr}
\hline \multicolumn{1}{c}{ Corridor } & \multicolumn{1}{c}{ Revenue } \\
\hline Sumatera Corridor & USD & $169,638,434,368$ \\
Java Corridor & USD & $465,829,816,641$ \\
Kalimantan Corridor & USD & $43,071,852,780$ \\
Sulawesi Corridor & USD & $103,380,830,663$ \\
Bali-Nusa Tenggara Corridor & USD & $37,151,563,779$ \\
Papua-Maluku Corridor & USD & $53,309,556,215$ \\
\hline TOTAL & USD & $872,382,054,446$ \\
\hline
\end{tabular}

After identifying the values of each cost component, the LCC analysis was conducted to obtain the IRR and NPV. Based on the calculation, the IRR is $11.51 \%$, and the calculated NPV is USD 254 million. Based on this value, it can be determined that the project is financially feasible since the IRR value is greater than the WACC value of $11.01 \%$. A positive NPV value $(\mathrm{NPV}>0)$ also indicates that the project is financially feasible. However, the feasibility level for this project still needs to be increased to improve the private sector's interest to participate in this project.

\subsection{Financing Scheme}

A simulation of four types of cost-sharing schemes between the government and the private sector was conducted to increase the project's attractiveness for the private sector by generating an optimum IRR value. The four financing schemes include the initial costsharing scenario, the OM cost-sharing scenario, the initial cost and OM cost-sharing scenario, and the initial cost, OM cost, and revenue sharing scenario.

Based on Minister of Finance Regulation Number 223/PMK.01/2012 concerning Procedures for Electronic Procurement of Goods/Services, the range of the cost-sharing scenario for the initial cost and OM cost is $40 \%, 50 \%$, and $60 \%$, with similar division of 
responsibility between public and private sector. The sharing scenarios for the revenue between the government and the private sector are $60 \%, 70 \%$, and $80 \%$. There was a total of 45 cost-sharing scenarios produced using this combination.

\subsubsection{Initial cost-sharing scenario}

In the initial cost-sharing scenario, the sharing option that produces the highest IRR (i.e., $22.56 \%$ ) is when the government contributes $60 \%$ of the initial cost. The advantage of this scheme is that the government can focus on other projects, since the private sector has a greater responsibility in operating the project. In addition, the project preparation stage will be more effective and efficient. However, this is also very profitable from the private sector's perspective, because $100 \%$ of the revenue generated belongs to the private sector. The disadvantage of using this cost-sharing scheme is that the government cannot supervise the project's operation since its role is only in the early stage of project development. It can also negatively impact the surrounding community because the procedures conducted by the private sector throughout the operational stage cannot be closely supervised and controlled.

\subsubsection{OM cost-sharing scenario}

In the OM cost-sharing scenario, the option that produces the highest IRR is when the government is responsible for $60 \%$ of the OM cost, resulting in an IRR of $16.03 \%$, which is lower than that in the initial cost-sharing scenario. However, the advantage of this costsharing scenario is that the government has the right to supervise, control, and regulate policies throughout the operational project stage, which can minimize the chance of monopolies and unjust capitalization. In addition, the government can obtain and expand its knowledge on technological advancement, innovation, and management through the private sector during the project operation and maintenance stage.

\subsubsection{Initial cost \& OM cost-sharing scenario}

The third cost-sharing scenario might be the most attractive scenario for the private sector, considering its return on investment. The sharing option with the most optimal IRR is when the government contributes $60 \%$ of the initial and OM costs with an IRR of $29.80 \%$, which is higher than the two options mentioned above. This scheme has the most advantages, since it combines the previous two scenarios. However, it also has particular disadvantages for the government since it puts a heavy cost burden on the government without gaining any revenue in return, which is not financially equitable.

\subsubsection{Initial cost, $\mathrm{OM}$ cost, \& revenue sharing scenario}

Although not as attractive as the third scenario, the fourth scenario might be the most equitable financing scheme compared with all the other three cost-sharing scenarios explained above. In this scenario, the government not only shares the initial and OM cost burden but also gets a share of the revenue. The optimal financing option in terms of IRR in this scenario is when the government covers $60 \%$ of the initial and OM costs and gets $20 \%$ revenue. This particular option generates an IRR of $25.26 \%$.

However, there is another preferable option; the government covers $40 \%$ of the initial cost and $50 \%$ of the OM cost, and is entitled to $20 \%$ revenue. The share of costs and revenue was then further adjusted by considering the distribution of involvement of both the public and private sectors in the project investment. Thus, the financing scheme with the shares of the initial cost, OM cost, and revenue, as shown in Table 4, was found to be the most optimal and feasible scheme for this investment, which produces an NPV of USD $226,745,365,064$ and IRR of $15.62 \%$, which is higher by $4.11 \%$ compared with the initial financing scheme, in which the government covers none of the cost burden and the revenue. 
Table 4 Financing scheme with optimum NPV and IRR

\begin{tabular}{cccc}
\hline Entity & Initial cost & OM Cost & Revenue \\
\hline Private & $64.14 \%$ & $73.61 \%$ & $76.62 \%$ \\
Government & $35.86 \%$ & $26.39 \%$ & $23.38 \%$ \\
\hline
\end{tabular}

In this financing scheme, the government is responsible for $35.86 \%$ of the total initial cost, comprising the costs to develop $40 \%$ of power plants, ports, airports, broadband, and highway. The government is also responsible for these infrastructures' OM cost, which constitutes around $26.39 \%$ of the total OM cost. The revenue generated from these infrastructures, which constitutes $23.38 \%$ of the total revenue, would be granted to the government. Other infrastructures, such as industrial factories, smelter, modern mining infrastructure, Denpasar tram, docks, near field communication (NFC), mobile applications, railway infrastructure, and the rest of the power plant, would be the private sector's responsibility and source of revenue.

\subsection{Institutional Scheme}

This research developed a PPP institutional scheme for industrial infrastructure project development in which various parties are involved, including a special purpose vehicle (SPV). Other parties involved in this cooperation are the Japan International Cooperation Agency (JICA), planning consultant, industrial consultant, transportation consultant, BAPPENAS, National Public Procurement Agency (LKPP), Indonesia Infrastructure Guarantee Fund (IIGF), the providers of operation and maintenance services, and financial institutions such as banks and non-banks (i.e., PT Sarana Multi Infrastruktur (SMI) and a special mission vehicle (SMV) under the Ministry of Finance engaging in financing infrastructure projects).

JICA, as an incorporated administrative agency, aims to contribute to the promotion of international cooperation as well as the sound development of the Japanese and global economy by supporting the socioeconomic development, recovery, and economic stability of developing regions. In the proposed PPP scheme, JICA would function as a consultant that helps develop industrial infrastructure projects.

The planning consultant would be the leading consultant and coordinator throughout the planning and construction stages of the project. During the planning stage, the consultant would develop the master plan and design of the project. The consultant would also be in charge of other supporting documents, such as permits, budget plan, detailed engineering design, etc. Throughout the construction stage, the consultant would supervise project execution to ensure compliance with the original plan and standards. Furthermore, an industrial consultant is proposed in this study to analyze the industry potential, requirements, and production capacity for each industrial sector in each corridor. Since the availability of adequate transportation infrastructure and effective transportation systems can improve connectivity and facilitate access between regions, especially for the distribution of goods and services, the role of a transportation consultant in preparing the plan and designing the transportation infrastructure, ranging from ports, roads, airports, and railway networks, is necessary. In addition, the transportation consultant would also analyze traffic engineering and control traffic conditions around the project development site to minimize disturbance to the surrounding communities caused by infrastructure development.

BAPPENAS is in charge of establishing a list of PPP project plans, and it would be acting as the coordinator of the PPP project. Meanwhile, IIGF, as an Indonesian state-owned enterprise (SOE), provides a guarantee that is essential to increase the private sector's interest and trust in participating in a PPP project. Furthermore, the involvement of 
financial institutions would be required to support the financial aspect of the project; they act as lenders for the government and private entities.

The proposed institutional scheme shown in Figure 4 was validated through in-depth interviews with PPP experts and stakeholders dealing with the implementation of PPP projects in Indonesia, such as Indonesian ministries and non-bank financial institutions. The financing and institutional schemes have been upgraded following the experts' feedback obtained from the interviews; therefore, the proposed schemes are deemed applicable and follow PPP regulations. The result of this study inclines with the study conducted by Kim and Wi (2019), stating that PPP projects, particularly those with a solid institutional framework, can deliver financial benefits by closing infrastructure gaps and increasing economic growth.

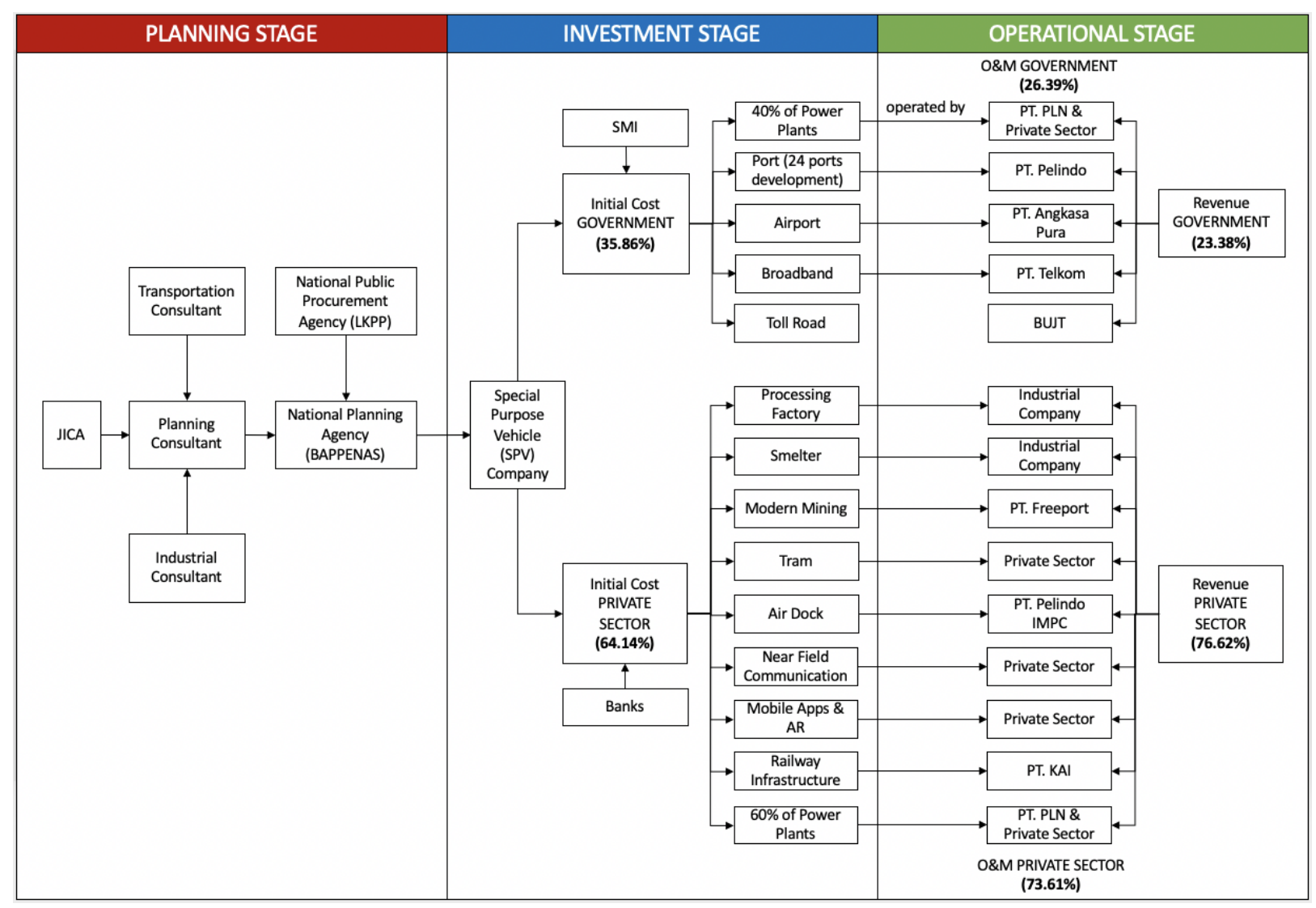

Figure 4 Institutional scheme

\section{Conclusions}

One of the key strategies for Indonesia to achieve its vision of being a developed economy by 2045 is through infrastructure development and thereby improving connectivity in the economic corridors to facilitate economic activities. However, as the government experiences budget constraints for funding the required infrastructure development, the involvement of alternative financing sources through a partnership scheme involving the private sector is necessary. The optimal cost-sharing scenario of the PPP financing scheme for industrial infrastructure development in the six economic corridors in Indonesia proposed in this study generated an IRR of $15.62 \%$, which demonstrates that the cost-sharing scheme provides a more optimal financing option with a higher IRR value and equitable allocation of responsibilities and risks.

An institutional scheme for project development was developed to adhere to the proposed financing scheme, which involves planning consultants, JICA, BAPPENAS, 
National Public Procurement Agency, financial institutions, IIGF, private companies, and state-owned enterprises as the operators of the industries. Synergy among these entities would be required to ensure that the infrastructure projects delivered through the PPP scheme could support Indonesia in realizing its economic development vision for the year 2045. This study encourages further research to consider the social benefits obtained from infrastructure development as a positive externality that increases a project's financial feasibility.

\section{Acknowledgements}

This research was supported by the Ministry of Research and Technology, Republic of Indonesia (NKB-2853/UN2.RST/HKP/05/00/2020).

\section{References}

Azolibe, C.B., Okonkwo, J.J., 2020. Infrastructure development and industrial sector productivity in Sub-Saharan Africa. Journal of Economics and Development, Volume 22(1), pp. 91-109

Bank Indonesia, 2021. BI 7-Day (Reverse) Repo Rate. Bank Indonesia. Available Online at https://www.bi.go.id/en/statistik/indikator/bi-7day-rr.aspx

BAPPENAS, 2020. Public-Private Partnerships Infrastructure Project Plan in Indonesia 2020

Berawi, M.A., Miraj, P., Sidqi, H., 2017. Economic Corridor of Industrial Development in Indonesia. In: IOP Conference Series: Earth and Environmental Science, Volume 109(1)

Berawi, M.A., Nabila, A., Gunawan, Miraj, P., Rahman, H.A., Berawi, A.R.B., 2018. Analysis of Life Cycle Cost and Public-Private Partnership in the Development of Walini City as Technology Park. International Journal of Technology, Volume 9(7), pp. 1469-1479

Berawi, M.A., Susantono, B., Miraj, P., Sari, M., Saroji, G., Berawi, A.R.B., Sidqi, H., 2020. Accelerating Nation Competitiveness Through Economic Corridor Development: Indonesia Masterplan Revisited. Communications in Computer and Information Science, 1273 CCIS, pp. 77-100

Blank, L., Tarquin, A., 2013. Engineering Economy; Seventh Edition. Journal of Chemical Information and Modeling, pp. 1-645

Calderón, C., Servén, L., 2004. The Effects of Infrastructure Development on Growth and Income Distribution. Policy Research Working Paper, Volume 3400, pp. 1-43

Hansen, S., Too, E., Le, T., 2018. Lessons Learned from a Cancelled Urban Transport Project in a Developing Country: The Importance of the Front-End Planning Phase. International Journal of Technology, Volume 9(5), pp. 898-909

Kelly, J., Morledge, R., Wilkinson, S., 2003. Value in Construction. Blackwell Publishing in conjunction with RICS Foundation

Kim, J., Wi, S., 2019. Delivering Economic Benefits from Public-Private Partnerships: The Experience of the Republic of Korea. In A. Deep, J. Kim, \& M. Lee (Eds.), Realizing the Potential of Public-Private Partnerships to Advance Asia's Infrastructure Development (p. 359). Asian Development Bank

Komarova, V.N., Zjablova, O.V., Denmukhametov, R.R., 2014. An Infrastructure Factor in Regional Competitiveness. Mediterranean Journal of Social Sciences, Volume 5, pp. 1-6

López, H., 2003. Macroeconomics and Inequality. In Washington DC: The World Bank Processed, pp. 1-29

Mandasari, V., Wahyuni, E.T., 2019. Infrastructure Development by Public-Private Partnership in Indonesia: A Systematic Literature Review. CSID Journal of Infrastructure Development, Volume 2(2), pp. 153-160 
Mian, M.A., Vélez-Pareja, I., 2007. Applicability of the Classic WACC Concept in Practice. Latin American Business Review, Volume 8(2), pp. 19-40

Negara, S.D., Ramayandi, A., 2020. Laying the Foundations for Future Growth Acceleration? Bulletin of Indonesian Economic Studies, Volume 56(1), pp. 1-21

Palei, T., 2015. Assessing the Impact of Infrastructure on Economic Growth and Global Competitiveness. Procedia Economics and Finance, Volume 23, pp. 168-175

Piroozfar, P., Pomponi, F., Farr, E.R.P., 2016. Life Cycle Assessment of Domestic Hot Water Systems: A Comparative Analysis. International Journal of Construction Management, Volume 16(2), pp. 109-125

Snieška, V., Bruneckiene, J., 2009. Measurement of Lithuanian Regions by Regional Competitiveness Index. Engineering Economics, Volume 1(61), pp. 45-57

Sterman, J.D., 2000. System Dynamics: Systems Thinking and Modeling for a Complex World. Irwin/McGraw-Hill

Strano, A., Irene De Luca, A., Falcone, G., Iofrida, N., Stillitano, T., Gulisano, G., 2013. Economic and Environmental Sustainability Assessment of Wine Grape Production Scenarios in Southern Italy. Agricultural Sciences, Volume 4(5B), pp. 12-20

Tijaja, J., Faisal, M., 2014. Industrial Policy in Indonesia: A Global Value Chain Perspective. In: The ADB Economics Working Paper Series (No. 411), pp. 1-44

Timmer, M.P., Inklaar, R., OMahony, M., van Ark, B., 2011. The Industry Origins of Aggregate Growth. Economic Growth in Europe, pp. 152-188

WACC Expert, 2020. WACC for Construction and Materials Sector in Indonesia

Yuliawati, E., Hadiwardoyo, S.P., Susantono, B., Tjahjono, T., 2015. System Dynamics Model for Airport Characterization in Hub-and-Spoke Networks. International Journal of Technology, Volume 6(5), pp. 733-742

Zhang, J., Zhang, R., Xu, J., Wang, J., Shi, G., 2021. Infrastructure Investment and Regional Economic Growth: Evidence from Yangtze River Economic Zone. Land, Volume 10(3), pp. 1-14 